\title{
RELIABILITY DESIGN OF THE CASTING MACHINES UNDER HIGH PRESSURE
}

\author{
Eleonora Desnica, Ivica Nikolić, Vladimir Trninić, Mirjana Bojanić
}

Professional paper

The basic aim of this paper is to estimate possible hazards at casting machines under high pressure in production conditions, by failure modes and effect analysis (FMEA) method. Providing high reliability, safeness and quality in the use of any technical system (TS), is a complex task for designers, engineers, technologists in the process of production and maintenance. The example, shown in the paper (casting machines under high pressure), can be used for the analysis of the reliability in the design phase and in the exploitation period of many processes in the machine industry. For this purpose an "adjusted" (simplified) procedure for failure analysis has been developed. Analysis was conducted in the production conditions in the factory FAM Secanj, Serbia. In the paper, we evaluated the failure at four casting machines by using FMEA method and by using FMEA Worksheets according to standard SRPS EN 60812:2011. Based on the $R P N$ value (Risk Priority Number) certain corrective actions have been implemented. By application of these actions, it is possible to predict the maintenance procedures of the system in order to provide the required reliability during operation of the system.

Keywords: casting machines under high pressure; FMEA; reliability design; RPN (Risk Priority Number)

Projektiranje pouzdanosti strojeva za lijevanje pod visokim tlakom

Stručni članak

Osnovni cilj ovog rada je procjena moguće pojave otkaza kod stroja za lijevanje pod visokim tlakom u proizvodnim uvjetima, uporabom metode analize načina otkaza i njihovih efekata (FMEA - metoda). Obezbjeđenje visoke pouzdanosti, sigurnosti funkcioniranja i kvaliteta u uporabe svakog tehničkog sustava (TS), predstavlja složen zadatak koji se postavlja pred konstruktore i projektante, tehnologe u proizvodnji, inženjere u održavanju. Primjer prikazan u radu (strojevi za lijevanje pod visokim tlakom) može poslužiti za analizu pouzdanosti u fazi projektiranja i u razdoblju eksploatacije kod mnogih procesa u strojarskoj industriji. U tu svrhu je razvijen "prilagođen" (pojednostavljen) postupak za analizu otkaza. Analiza je provedena u proizvodnim uvjetima u tvornici FAM Sečanj, Srbija. U radu je analizirana pouzdanost četiri stroja za lijevanje pomoću FMEA metoda, uz uporabu FMEA radnih listova prema normi SRPS EN 60812:2011. Na osnovu vrijednosti RPN (broj prioriteta rizika) određene su i provedene određene korektivne mjere. Primjenom ovih korektivnih mjera, moguće je predvidjeti postupke održavanja sustava u cilju obezbjeđenja zahtjevane pouzdanosti tijekom eksploatacije sustava.

Ključne riječi: FMEA; projektiranje pouzdanosti; strojevi za lijevanje pod visokim tlakom; RPN (broj prioriteta rizika)

\section{Introduction}

Complex equipment and devices used in any system constitute majority of the capital invested in industry. Equipment is subject to deterioration with usage and time and deterioration is often reflected in higher operation costs and lower service quality [1].

Today, high reliability is required of technical systems in enterprises in terms of minimizing failure conditions and almost completely eliminating critical places. On the other hand, technical systems are increasingly complex, more productive and, of course, more expensive. Their failure, i.e. the halt (production line with a number of machines, high-productivity machines, etc.) causes high losses due to a failure of the basic function [2]. This is particularly noticeable in the process industry (cars industry, petrochemical plants, refineries, production of the cellulose, cement or sugar), where, due to the failure of only one part of the technical system comes to the halt of the entire production line, if there are no parallel technical systems, which gives greater reliability of the process, but significantly more expensive investments $[3,4]$.

Many companies think of maintenance as an inevitable source of cost. For these companies maintenance operations have a corrective function and are only executed in emergency conditions [5].

The design process must be organized to ensure that failure-free design principles are used and that any deviations from the principles are detected and corrected. Processes and products need to be standardized and maintenance needs to be planned. Routine maintenance activities require to be carried out by operators to allow maintenance personnel to schedule modification and maintenance programs [6].

The competitiveness on the market worldwide, has led to the fact that among maintain-engineers is known the acronym TPM (total productive maintenance), a maintenance concept similar to TQM (total quality management). Most companies begin to realize what TPM actually is - systematic improvement in quality, delivery and cost reduction through participation of the whole company, people and equipment. TPM puts into focus the maintenance as necessary and vital part of the production and management [7].

Mobley in [8] cites several basic causes for failures of equipment appearing. They are: misapplication, operating practices, maintenance practices, age and management systems. Understanding of these causes allows the choice of appropriate strategies for monitoring equipment and systems, predicting possible failures and determination of the adequate corrective measures.

On the other hand, the maintenance costs of the TS are $15 \div 40 \%$ of total operation costs, estimated by Mobley in [9]. This fact caused a new approach in the modern design process - design for reliability (DfR) [10]. To provide information for DfR, certain methods of failure analysis on the technical system should be conducted. Failure Mode and Effects Analysis (FMEA) is based on consideration of all potential failures in the component parts of the system and their effects on the system. Since a complex mechanical systems have a large number of component parts (all the parts do not have the same importance for the reliability of the system), ranking 
of the parts is carried out according to their significance, from the standpoint of reliability in order to achieve certain operability. By this method it is possible to obtain reliable corrective measures whose implementation will significantly reduce total life cycle costs, which is the ultimate goal. The need for increased productivity and equipment safeness, and thereby reduced maintenance costs, has led to increased interest in methods for monitoring of the casting machines under high pressure. The application of FMEA method on these machines is possible in order to ensure the required reliability during operation of the system and to provide increasing life cycle of a technical system.

Also, Falcone et al. in [11] suggest a simple, but suitable method for ranking risks in a company, in order to reach the maximum effectiveness of prevention and protection strategies. They proposed an integration of the popular failure mode and criticality analysis (FMECA) with other factors of cost and effectiveness. This is a good basic point for "adjustment" of traditional FMEA/ FMCEA methods for own and specific need. In our research we used this methodology.

\section{Material and method}

Researches, presented in the paper, have been conducted in the casting factory FAM Secanj, Serbia, which is in the scope of the CIMOS automotive group. Until now, a more significant research in this field in Serbia and region has not been conducted.

Similar casting factories are in the countries in the region such as Croatia, Slovenia, Italy, Austria, and Germany.

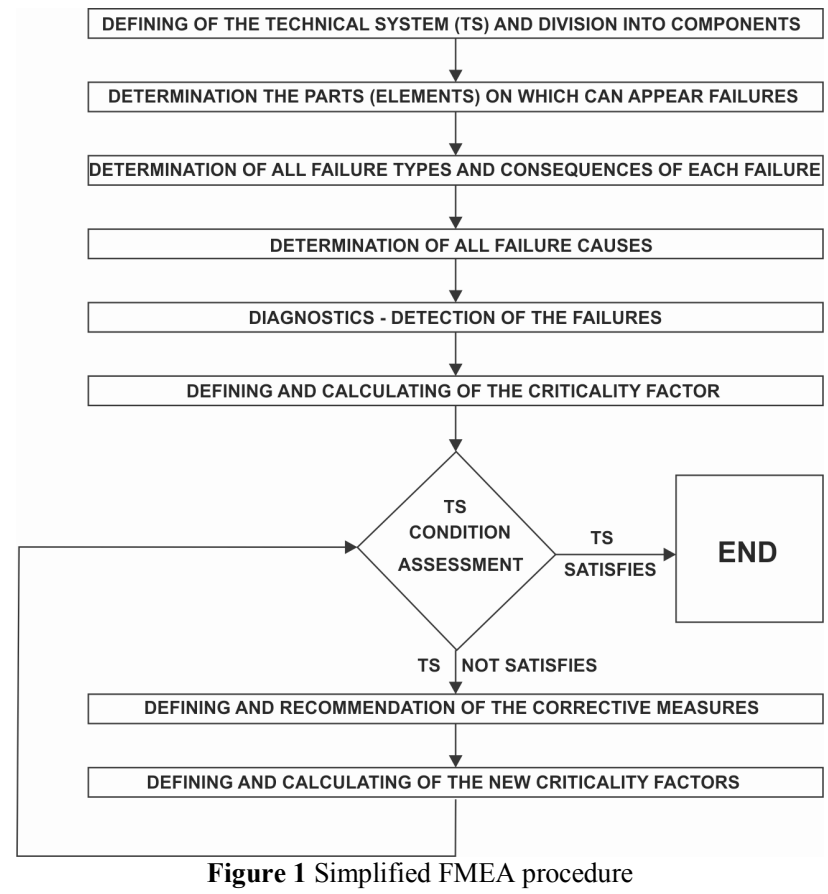

In the factory there are twelve (12) casting machines. We evaluated the risks on four casting machines under high pressure (Idra OL 700, Litostroj HTS 850, Colosio 1000 and Buhler 840D) using FMEA method, based on the facts in [12] where the cases when FEMA method should be used have been proposed. In our opinion, results obtained for four machines should be similar for the other eight, because all machines operate under the same production and climate conditions.

To overcome problems concerning the provision of necessary information and the difficulties related to specific structure of the casting machines, we developed an "adjusted" (simplified) FMEA procedure which is shown in Fig. $1[3,4]$. In the simplified procedure, calculation of the criticality factor is included.

\subsection{RPN Methodology}

During the FMEA procedure, for decision making, $R P N$ scoring and crisis level has been used. The $R P N$ is a mathematical product of the severity, the occurrence and the detection, and is used to compare the failures during the analysis and to define priorities for undertaking of the corrective actions $[13 \div 15] . R P N$ is obtained by multiplying three factors of intensity, possibility of occurrence, and detection possibility $[13,15] . R P N$ is calculated as:

\section{$R P N=$ Severity $\times$ Occurrence $\times$ Detection}

The $R P N$ is obtained by the multiplication of three factors: severity of the failure $(S)$, probability of occurrence $(O)$ and probability of detection $(D)$. In our research, we used risk criterion number to determine the level of acceptable and unacceptable risk in $R P N$. Risk criterion is an index for separating acceptable and unacceptable risks in the reliability design process. A failure with $R P N$ number greater than the risk criterion is considered as unacceptable risk and a failure with $R P N$ lower than the risk criterion is called acceptable risk. Qualitative scales $(1 \div 10)$ used for the severity, the occurrence and the detection are presented in $[13,15]$. $R P N$ provides a means to prioritize which components should be evaluated by the experts for reliability in order to reduce their calculated risk through some type of corrective actions or maintenance efforts. In [15] it is emphasized that, when severity is at a high level, immediate corrective actions may be given regardless of the resultant $R P N$. In our research we considered that in the case $R P N>100$, corrective actions are necessary.

Although we adopted the $R P N$ methodology as authoritative for the implementation of corrective actions, we must point out that there are different opinions on the validity of the mentioned methodology.

Pillay at al. in [16] concluded: "When conducting an FMEA for safety assessment purposes, precision should not be forced where data is unreliable and scarce. Hence, to ask an analyst or an expert to assign scores ranging from 1 to 10 (as done in the $R P N$ method) for the different factors considered would produce a false and unrealistic impression. The use of linguistic terms in the proposed approach allows for the experts to assign a more meaningful value for the factors considered. This ensures that identified events do not get overlooked (due to low $R P N$ ) when considering the priority for attention".

Popovic et al. in [14] emphasize: "As a result, some variants of $S-O-D$ product give $R P N$ which is smaller than other combinations, but with more risk. The high value of severity requires a great deal of attention, especially when 
it is coupled with a high value of failure occurrence. The term criticality has been developed to focus the attention on these combinations. A separate problem while using $R P N$ values lies in the fact that failure detection value does not accurately measure the contribution to the risk".

Ben-Daya et al. in [17], based on the analysis of the critique of FMEA, suggest development of new $R P N$ model which should include cost model, in order to obtain better results in $R P N$ determination.

In [18] is described a new approach - extended in the risk prioritizing of the possible failures. A new scale is also proposed in order to overcome weaknesses of the conventional $R P N$ methodology. It is very important for definition of the corrective measures.

In [19] authors concluded that it is possible obtain identical $R P N$ for different failures, in spite of the fact that particular indexes (Severity $\times$ Occurrence $\times$ Detection), which are included in $R P N$, are different. They propose a new approach - Risk Priority Code (RPC), which prioritizes failure modes in the case when some failure modes have identical $R P N$.

The case study presented in the paper [17] "resolves the limitations of traditional FMEA technique. If two or more failure modes have the same $R P N$, it is possible to prioritize the failure modes with the help of Risk Priority Code (RPC) ".

In paper [20], authors emphasize that the FMEA is still not completely accepted. The paper presents ideas and approaches how problems concerning FMEA can be encountered and which influences and/or changes derive from that for future FMEA-sessions.

In spite of the opinion previously presented, in our research and practical application we accepted Failure
Mode and Effects Analysis (FMEA) and $R P N$ methodology. As confirmation of our decision to use the mentioned principles, let it be the fact presented in [21]. "Failure Mode and Effects Analysis (FMEA) can anticipate and prevent problems and help companies achieve high reliability in products and processes within considerably shorter development time, and within budget".

\section{Results and discussion}

Our research was conducted during two years, 2013 and 2014. First research part was conducted during 2013. and refers to exploitation period before corrective actions. It was a monitoring period for four casting machines. For each machine, for every month in the year the reliability level, in \%, was calculated. Data - information that have been collected for research, were obtained through direct contact (investigation), and on the basis of the experiences of mechanics and engineers, during the period of machines for casting maintenance. In Tab. 1, reliability levels for each machine, for each month in 2013 are shown.

Tab. 1 shows that, in terms of reliability, machines Litostroj and Colosio had a decrease of reliability during the summer period. It can be useful information for designer in order to prevent overheating and increase tolerance of the machine on high temperatures of the environment.

Based on the data from Tab. 1, in Fig. 2, comparative review of the average reliability levels for each machine in 2013 are shown.

Table 1 Reliability level of the casting machines in 2013

\begin{tabular}{|c|c|c|c|c|c|c|c|c|c|c|c|c|}
\hline \multirow{2}{*}{ Casting Machine } & \multicolumn{12}{|c|}{ Reliability level - for month (\%) } \\
\hline & I & II & III & IV & $\mathrm{V}$ & VI & VII & VIII & IX & $X$ & XI & XII \\
\hline Idra OL 700 & 81,8 & 85,6 & 90,9 & 70,6 & 80,7 & 83,5 & 73,9 & 75,6 & 80,3 & 90,6 & 80,3 & 80,2 \\
\hline Litostroj HTS 850 & 75,4 & 73,4 & 72.9 & 75,5 & 72,2 & 65,7 & 63,5 & 60,0 & 66,0 & 70,1 & 72,5 & 80,0 \\
\hline Colosio 1000 & 75,8 & 76,4 & 75,7 & 77,6 & 73,6 & 68,2 & 66,9 & 66,3 & 67,1 & 73,6 & 78,4 & 77,7 \\
\hline Buhler $840 \mathrm{D}$ & 77,2 & 76,4 & 77,6 & 83,9 & 79,3 & 72,6 & 71,8 & 77,2 & 82,6 & 83,0 & 77,4 & 77,3 \\
\hline
\end{tabular}

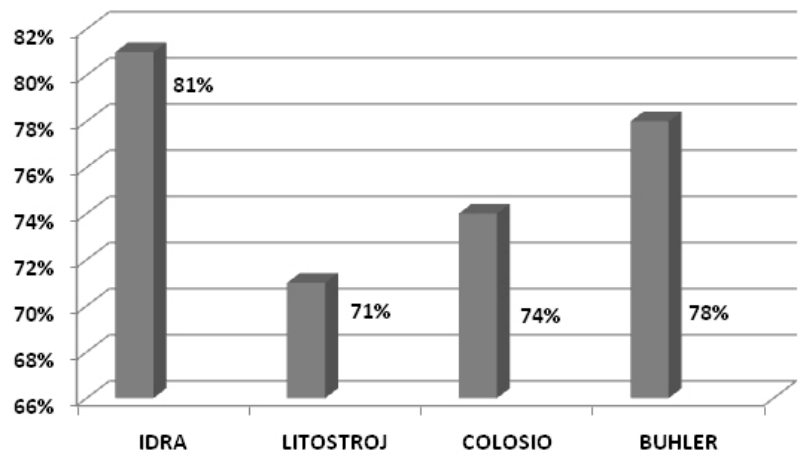

Figure 2 Average reliability levels for each machine in 2013.

In FAM Secanj a diagnostic table has been established [22] about possible causes of failures on casting machines. Based on the diagnostic table, Tab. 2 shows a sample of the FMEA Worksheet, according to standard SRPS EN 60812:2011 [23], which represents an analysis of modes and effects of failures through FMEA procedure in 2013.

As earlier mentioned, $R P N$ methodology is used to help in identifying the principal risks, and to show us the way for corrective activities. Also, we determined, based on personal experience, limit $R P N$ value $(>100)$ for need of corrective actions

Type of corrective activities, which we proposed, is based on our experience in the design of the reliability of casting machines.

Analysis of the results of FMEA procedure for 2013 shows that a corrective action has to be applied wherever $R P N$ is over 100 (what can be seen in Tab. 2). We concluded that (based on $R P N$ value), because of the occurrence of overheating problems of casting machines under high pressure, it is necessary to apply two corrective actions. First corrective measure is the application of 306 Hydrocid means for conditioning water in the cooling system throughout the entire plant, where research has been carried out. Second corrective measure is the application of the plate heat exchanger TR 200 on

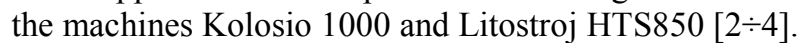

Hydrocid 306 is a broad spectrum biocide for the control of bacteria, algae, fungi and slimes in water systems. It can be used very successfully in industrial cooling systems. In our case we used Hydrocid 306 to 
remove deposits of slimes in the cooling system of the casting machines under high pressure.

All information concerning water conditioner Hydrocid 306 and plate heat-exchangers TR 200: technical drawing, method of application, description of chemicals, technical characteristics and materials is given in $[3,4,22]$.

Table 2 FMEA method - Worksheet before corrective actions, for 2013

\begin{tabular}{|c|c|c|c|c|c|c|c|c|c|c|}
\hline Part & Function & $\begin{array}{l}\text { Mode of } \\
\text { failures }\end{array}$ & $\begin{array}{l}\text { Failure } \\
\text { effects }\end{array}$ & Severity & $\begin{array}{l}\text { Cause of } \\
\text { failure }\end{array}$ & $\begin{array}{c}\text { Probability } \\
\text { of } \\
\text { occurrence }\end{array}$ & $\begin{array}{l}\text { Detection of } \\
\text { failure }\end{array}$ & Detection & $R P N$ & Action \\
\hline $\begin{array}{l}\text { Third phase } \\
\text { multiplier }\end{array}$ & $\begin{array}{c}\text { Third phase } \\
\text { pressure }\end{array}$ & $\begin{array}{c}\text { Insufficient } \\
\text { third phase } \\
\text { pressure }\end{array}$ & $\begin{array}{l}\text { Casting drip } \\
\text { porosity }\end{array}$ & 9 & Battery leakage & 5 & $\begin{array}{l}\text { Pressure } \\
\text { gauge }\end{array}$ & 2 & 90 & $\begin{array}{c}\text { Check-ups } \\
\text { on hourly } \\
\text { basis }\end{array}$ \\
\hline $\begin{array}{l}\text { Dosing } \\
\text { furnace } \\
\text { heaters }\end{array}$ & $\begin{array}{l}\text { Maintenance } \\
\text { of casting } \\
\text { temperature } \\
\text { in the furnace }\end{array}$ & $\begin{array}{l}\text { Faulty } \\
\text { heater }\end{array}$ & $\begin{array}{c}\text { Temperature } \\
\text { (casting) } \\
\text { under the } \\
\text { limit }\end{array}$ & 8 & Cracked heater & 4 & $\begin{array}{c}\text { Furnace } \\
\text { ammeter } \\
\text { heater display }\end{array}$ & 2 & 64 & $\begin{array}{c}\text { Read } \\
\text { parameters } \\
\text { on hourly } \\
\text { basis } \\
\end{array}$ \\
\hline $\begin{array}{c}\text { Second } \\
\text { phase valve }\end{array}$ & $\begin{array}{l}\text { Regulation of } \\
\text { second phase } \\
\text { speed }\end{array}$ & $\begin{array}{c}\text { Second } \\
\text { phase valve } \\
\text { failure }\end{array}$ & $\begin{array}{c}\text { Second phase } \\
\text { low } \\
\text { (excessive) } \\
\text { speed } \\
\end{array}$ & 8 & $\begin{array}{c}\text { Operation } \\
\text { blockage (dirty } \\
\text { oil) }\end{array}$ & 4 & $\begin{array}{c}\text { Second phase } \\
\text { display }\end{array}$ & 2 & 64 & $\begin{array}{l}\text { Preventive } \\
\text { cleaning } \\
\text { once a } \\
\text { month } \\
\end{array}$ \\
\hline $\begin{array}{c}\text { Heat } \\
\text { exchanger }\end{array}$ & $\begin{array}{l}\text { Cooling of } \\
\text { hydraulic oil } \\
\text { in the } \\
\text { machine }\end{array}$ & $\begin{array}{c}\text { Poor or } \\
\text { insufficient } \\
\text { flow }\end{array}$ & $\begin{array}{c}\text { Machine } \\
\text { malfunction } \\
\text { (oil } \\
\text { overheating) }\end{array}$ & 8 & $\begin{array}{l}\text { Insufficient } \\
\text { cooling } \\
\text { capacity }\end{array}$ & 7 & $\begin{array}{l}\text { Casting } \\
\text { machine } \\
\text { display }\end{array}$ & 2 & 112 & $\begin{array}{c}\text { Introduce } \\
\text { additional } \\
\text { cooling }\end{array}$ \\
\hline $\begin{array}{l}\text { Tools } \\
\text { coating } \\
\text { (cooling) } \\
\text { device }\end{array}$ & $\begin{array}{l}\text { Tool heat } \\
\text { dissipation }\end{array}$ & $\begin{array}{l}\text { Poor tools } \\
\text { spraying }\end{array}$ & $\begin{array}{l}\text { Overheated } \\
\text { tool }\end{array}$ & 9 & $\begin{array}{c}\text { Nozzle } \\
\text { contamination } \\
\text { (algae in the } \\
\text { system) }\end{array}$ & 6 & $\begin{array}{c}\text { Digital } \\
\text { thermometer }\end{array}$ & 2 & 108 & $\begin{array}{l}\text { Use biocide } \\
\text { within the } \\
\text { system } \\
\text { (anti-algae) }\end{array}$ \\
\hline Casting tool & Casting drips & $\begin{array}{c}\text { Tools } \\
\text { insufficient } \\
\text { cooling flow }\end{array}$ & $\begin{array}{l}\text { Cracked } \\
\text { pieces } \\
\text { (casting } \\
\text { drips) }\end{array}$ & 9 & $\begin{array}{l}\text { Algae within } \\
\text { the system } \\
\text { (clogged } \\
\text { cooling } \\
\text { channel) }\end{array}$ & 6 & $\begin{array}{c}\text { Float (for } \\
\text { water flow) }\end{array}$ & 2 & 108 & $\begin{array}{l}\text { Use CARB } \\
\text { bearings } \\
\text { C2314 } \\
\text { (vibration } \\
\text { resistant) } \\
\end{array}$ \\
\hline $\begin{array}{c}\text { Realization } \\
\text { pump } \\
\text { (hydraulic } \\
\text { pressure) }\end{array}$ & $\begin{array}{c}\text { System } \\
\text { pressurizing }\end{array}$ & $\begin{array}{l}\text { Pump } \\
\text { failure }\end{array}$ & $\begin{array}{c}\text { Insufficient } \\
\text { system } \\
\text { pressure }\end{array}$ & 8 & $\begin{array}{l}\text { Axis vibration } \\
\text { in gear pump } \\
\text { (pump } \\
\text { overheating) }\end{array}$ & 5 & $\begin{array}{c}\text { MIKROLOG } \\
\text { CMVA 65 } \\
\text { (Thermal } \\
\text { imaging) }\end{array}$ & 4 & 160 & $\begin{array}{c}\text { Replace } \\
\text { gear with } \\
\text { wing pumps }\end{array}$ \\
\hline
\end{tabular}

The second part of the research, which was conducted in 2014 after corrective actions, had the same concept as the first part. Again, for each machine for every month in the year reliability level, in \%, was calculated. In Tab. 3, reliability levels for each machine, for each month in 2014 are shown.

Table 3 Reliability level of the casting machines in 2014after corrective actions

\begin{tabular}{|c|c|c|c|c|c|c|c|c|c|c|c|c|}
\hline \multirow{2}{*}{ Casting Machine } & \multicolumn{12}{|c|}{ Reliability level - for month (\%) } \\
\hline & I & II & III & IV & $\mathrm{V}$ & VI & VII & VIII & IX & $\mathrm{X}$ & $\mathrm{XI}$ & XII \\
\hline Idra OL 700 & 82,3 & 83,7 & 86,9 & 81,8 & 92,6 & 83,5 & 78,5 & 79,6 & 81,8 & 81,0 & 83,0 & 79,3 \\
\hline Litostroj HTS 850 & 75,8 & 74,8 & 74,9 & 75,2 & 74,2 & 80,9 & 78,6 & 76,3 & 81,2 & 78,2 & 74,5 & 80,5 \\
\hline Colosio 1000 & 74,4 & 77,1 & 77,7 & 77,6 & 77,6 & 82,0 & 78,7 & 79,8 & 79,9 & 77,3 & 75,5 & 78,4 \\
\hline Buhler $840 \mathrm{D}$ & 79,2 & 83,4 & 79,6 & 76,4 & 77,3 & 76,8 & 76,6 & 82,2 & 77,6 & 81,0 & 78,4 & 79,6 \\
\hline
\end{tabular}

It can be noticed that, after corrective actions, reliability level of machines Litostroj and Colosio during the summer period significantly increased.

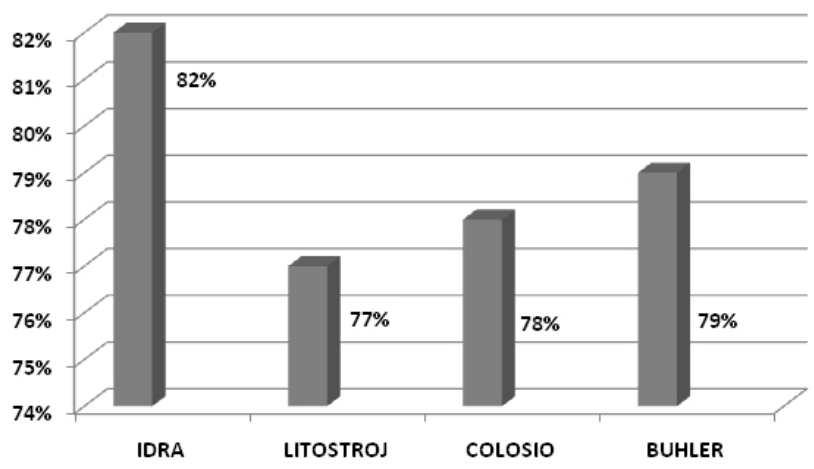

Figure 3 Average reliability levels for each machine in 2014 after corrective actions
Based on the data from Tab. 3, Fig. 3 shows comparative review of the average reliability levels for each machine in 2014 after corrective actions.

Tab. 4 shows a sample of the FMEA Worksheet according to standard SRPS EN 60812:2011 [23], which represents an analysis of modes and effects of failures through FMEA procedure in 2014, after corrective actions.

The application of both corrective actions has led to the increase in the level of reliability of machines for casting under high pressure, on the machine Litostroj HTS 850 by $6 \%$, while on the machine Colosio 1000 by $4 \%$. Also, by using failure modes and effect analysis (FMEA) method, and RPN methodology, we indicated, by presented functional tables, possible parts where failure can appear and modes and effects of failures.

These aforementioned results are in terms of improvements related exclusively to the reliability of the work which relates solely to thermal overheating of the 
machine. It was our basic goal, not the comprehensive analysis of other, possible, failure causes of machines.

Application of water conditioner Hydrocid 306 resulted by the improvements of reliability, in machines for the casting of a high-pressure Buhler $840 \mathrm{D}$ by $1 \%$ and Idra OL 700 by $1 \%$. These machines were not critically destabilized in the work by overheating for the periods of elevated temperatures.

If we take into consideration the summary, annual improvement for all machines is $12 \%$, what, for such a high batch production processes of casting under high pressure, represents a very large contribution and importance.

Table 4 FMEA method - Worksheet after corrective actions, for 2014

\begin{tabular}{|c|c|c|c|c|c|c|c|c|c|c|}
\hline Part & Function & $\begin{array}{l}\text { Mode of } \\
\text { failures }\end{array}$ & $\begin{array}{l}\text { Failure } \\
\text { effects }\end{array}$ & Severity & $\begin{array}{l}\text { Cause of } \\
\text { failure }\end{array}$ & $\begin{array}{c}\text { Probability } \\
\text { of } \\
\text { occurrence }\end{array}$ & $\begin{array}{l}\text { Detection of } \\
\text { failure }\end{array}$ & Detection & $R P N$ & Action \\
\hline $\begin{array}{l}\text { Third phase } \\
\text { multiplier }\end{array}$ & $\begin{array}{c}\text { Third phase } \\
\text { pressure }\end{array}$ & $\begin{array}{l}\text { Insufficient } \\
\text { third phase } \\
\text { pressure }\end{array}$ & $\begin{array}{l}\text { Casting drip } \\
\text { porosity }\end{array}$ & 9 & Battery leakage & 5 & $\begin{array}{l}\text { Pressure } \\
\text { gauge }\end{array}$ & 2 & 90 & $\begin{array}{c}\text { Check-ups } \\
\text { on hourly } \\
\text { basis }\end{array}$ \\
\hline $\begin{array}{l}\text { Dosing } \\
\text { furnace } \\
\text { heaters }\end{array}$ & $\begin{array}{l}\text { Maintenance } \\
\text { of casting } \\
\text { temperature } \\
\text { in the furnace }\end{array}$ & $\begin{array}{l}\text { Faulty } \\
\text { heater }\end{array}$ & $\begin{array}{c}\text { Temperature } \\
\text { (casting) } \\
\text { under the } \\
\text { limit } \\
\end{array}$ & 8 & Cracked heater & 4 & $\begin{array}{c}\text { Furnace } \\
\text { ammeter } \\
\text { heater display }\end{array}$ & 2 & 64 & $\begin{array}{c}\text { Read } \\
\text { parameters } \\
\text { on hourly } \\
\text { basis } \\
\end{array}$ \\
\hline $\begin{array}{c}\text { Second } \\
\text { phase valve }\end{array}$ & $\begin{array}{l}\text { Regulation of } \\
\text { second phase } \\
\text { speed }\end{array}$ & $\begin{array}{c}\text { Second } \\
\text { phase valve } \\
\text { failure }\end{array}$ & $\begin{array}{c}\text { Second phase } \\
\text { low } \\
\text { (excessive) } \\
\text { speed } \\
\end{array}$ & 8 & $\begin{array}{c}\text { Operation } \\
\text { blockage (dirty } \\
\text { oil) }\end{array}$ & 4 & $\begin{array}{l}\text { Second phase } \\
\text { display }\end{array}$ & 2 & 64 & $\begin{array}{c}\text { Preventive } \\
\text { cleaning } \\
\text { once a } \\
\text { month } \\
\end{array}$ \\
\hline $\begin{array}{c}\text { Heat } \\
\text { exchanger }\end{array}$ & $\begin{array}{l}\text { Cooling of } \\
\text { hydraulic oil } \\
\text { in the } \\
\text { machine }\end{array}$ & $\begin{array}{c}\text { Poor or } \\
\text { insufficient } \\
\text { flow }\end{array}$ & $\begin{array}{c}\text { Machine } \\
\text { malfunction } \\
\text { (oil } \\
\text { overheating) }\end{array}$ & 7 & $\begin{array}{l}\text { Insufficient } \\
\text { cooling } \\
\text { capacity }\end{array}$ & 5 & $\begin{array}{l}\text { Casting } \\
\text { machine } \\
\text { display }\end{array}$ & 2 & 70 & \\
\hline $\begin{array}{c}\text { Tools } \\
\text { coating } \\
\text { (cooling) } \\
\text { device } \\
\end{array}$ & $\begin{array}{l}\text { Tool heat } \\
\text { dissipation }\end{array}$ & $\begin{array}{l}\text { Poor tools } \\
\text { spraying }\end{array}$ & $\begin{array}{l}\text { Overheated } \\
\text { tool }\end{array}$ & 8 & $\begin{array}{c}\text { Nozzle } \\
\text { contamination } \\
\text { (algae in the } \\
\text { system) }\end{array}$ & 4 & $\begin{array}{l}\text { Digital } \\
\text { thermometer }\end{array}$ & 2 & 64 & \\
\hline Casting tool & Casting drips & $\begin{array}{c}\text { Tools } \\
\text { insufficient } \\
\text { cooling flow }\end{array}$ & $\begin{array}{l}\text { Cracked } \\
\text { pieces } \\
\text { (casting } \\
\text { drips) }\end{array}$ & 8 & $\begin{array}{l}\text { Algae within } \\
\text { the system } \\
\text { (clogged } \\
\text { cooling } \\
\text { channel) }\end{array}$ & 4 & $\begin{array}{c}\text { Float (for } \\
\text { water flow) }\end{array}$ & 2 & 64 & \\
\hline $\begin{array}{l}\text { Realization } \\
\text { pump } \\
\text { (hydraulic } \\
\text { pressure) }\end{array}$ & $\begin{array}{c}\text { System } \\
\text { pressurizing }\end{array}$ & $\begin{array}{l}\text { Pump } \\
\text { failure }\end{array}$ & $\begin{array}{l}\text { Insufficient } \\
\text { system } \\
\text { pressure }\end{array}$ & 7 & $\begin{array}{l}\text { Axis vibration } \\
\text { in gear pump } \\
\text { (pump } \\
\text { overheating) }\end{array}$ & 4 & $\begin{array}{l}\text { MIKROLOG } \\
\text { CMVA } 65 \\
\text { (Thermal } \\
\text { imaging) }\end{array}$ & 3 & 84 & \\
\hline
\end{tabular}

Factory FAM Secanj has 12 (twelve) casting machines under high pressure. After our two-year (2013 and 2014) research on the 4 (four) casting machines, application of the two corrective actions, we received results which show increase of the reliability of the mentioned four machines. We concluded that, with significant probability, these corrective actions can be applied on the other 8 (eight) machines.

\section{Conclusion}

Common causes of the failures on the casting machines under high pressure have been detected by research which was conducted. These knowledge should be implemented into design phase in order that in the exploitation phase the maintain methods can be more efficiently carried out. In this way smaller number of failures and halts of the system appear, system reliability increases and maintenance costs are reduced.

Exploitation research of this study showed that FMEA method can be successfully applied in complex technical system, such as in the case of the casting machines under high pressure, and that their use can achieve significant results in providing the reliability and quality of operation of the mentioned technical system with minimum maintenance costs. Also, the results of analysis can be used as feedback to designers, but also those who are engaged in maintenance.
Increasing of the reliability level using the FMEA methods and procedures, as well as the application of corrective measures (use of the destruction of algae and other impurities in the system and design of additional second heat exchanger) has led to the improvements in the exploitation of machines for casting under high pressure which we have tested.

With regard to the current work within the maintenance systems in the foundries in Serbia, as well as a more detailed study and monitoring of the means of mechanical (engineering) machinery, the same as on the above research, we can conclude that the methods FMEA/FMECA can be implemented into other technical systems within technical maintenance.

It should be emphasized that the results of the work, only a part of the research which would be necessary to carry in order for better understanding and application of FMEA/FMECA. The presented methodology can serve as a manner and directive in further implementation in practice of the above methods.

For future research we intend to conduct the comprehensive analysis of other, possible, failure causes of machines, and determine necessary corrective actions to overcome them, in order to achieve maximal possible reliability of the casting machines. 


\section{$5 \quad$ References}

[1] Savsar, M. Analysis and Scheduling of Maintenance, Operations for a Chain of Gas Stations. // Journal of Industrial Engineering. 2013(2013), pp. 1-7. https://doi.org/10.1155/2013/278546

[2] Desnica, E.; Radovanović, Lj.; Trninić, V. Ensure the Reliability During Exploitation of Casting Machines under High Pressure. // Proceedings of the Int. Conference Organization and technology of maintenance OTO 2015 / Osijek, 2015, pp. 109-114.

[3] Trninić, V.; Radovanović, Lj.; Adamović, Ž.; Decaban, R. Application of corrective measures from the aspect of increased level of reliability of casting machines under high pressure. // Proceedings of IV International Conference Industrial Engineering and Environmental Protection (IIZS 2014) / Zrenjanin, Serbia, 2014, pp. 159-163.

[4] Trninić, V.; Desnica, E.; Adamović, Ž. Application of failure modes and effects analysis method (FMEA) on casting machines under high pressure. // Proceedings of IV International Conference Industrial Engineering and Environmental Protection (IIZS 2014) / Zrenjanin, Serbia, 2014, pp. 164-167.

[5] Bevilacquaa, M.; Bragliab, M. The analytic hierarchy process applied to maintenance strategy selection. // Reliability Engineering and System Safety. 70, (2000), pp. 71-83. https://doi.org/10.1016/S0951-8320(00)00047-8

[6] Prasanth, S. P.; Pramod, V.R.; Jagathy Raj, V. P. Barriers in TPM Implementation in Industries. // International Journal of Scientific \& Technology Research. 2, 5(2013), pp. 2833.

[7] Cooke, F. L. Implementing TPM in plant maintenance: some organisational barriers. // International Journal of Quality \& Reliability Management. 17, 9(2000), pp. 10031016. https://doi.org/10.1108/02656710010378789

[8] Mobley, R. K. Root Cause Failure Analysis. Elsevier Butterworth-Heinemann, USA, 1999.

[9] Mobley, R.K. An Introduction to Predictive Maintenance. Van Nostrand Reinhold, New York, USA, 1990.

[10] O'Connor, P. D. T.; Kleyner, A. Practical Reliability Engineering. A John Wiley \& Sons, Inc. Publication, 2012.

[11] Falcone, D.; Silvestri, A.; Duraccio, V.; Di Bona, G.; Forcina, A. Safety Engineering: development of a new method for Risk Assessment, Efficient Risk Priority Number. // Proceedings of $1^{\text {st }}$ Global Virtual Conference. 2013, pp. 555-559.

[12] Tague's, N. C. The Quality Toolbox. ASQ Quality Press, Second Edition, 2004, pp. 236-240.

[13] Ebrahemzadih, M.; Halvani, G. H.; Shahmoradi, B.; Giahi, O. Assessment and Risk Management of Potential Hazards by Failure Modes and Effect Analysis (FMEA) Method in Yazd Steel Complex. // Open Journal of Safety Science and Technology. 4, (2014), pp. 127-135. https://doi.org/10.4236/ojsst.2014.43014

[14] Popović, V.; Vasić, B.; Petrović, M. The Possibility for FMEA Method Improvement and its Implementation into Bus Life Cycle. // Strojniški vestnik - Journal of Mechanical Engineering. 56, 3(2010), pp. 179-185.

[15] Technical Manual: Failure Modes, Effects and Criticality Analyses (FMECA) for Command, Control, Communications, Computer, Intelligence, Surveillance, And Reconnaissance (C4ISR) Facilities, Headquarters Department of The US Army. 2006. Available from: http://armypubs.army.mil/eng/DR_pubs/DR_a/pdf/tm5_698 4.pdf (20.02.2015)

[16] Pillay, A.; Wang, J. Modified failure mode and effects analysis using approximate reasoning. // Reliability Engineering and System Safety. 79, (2003), pp. 69-85. https://doi.org/10.1016/S0951-8320(02)00179-5
[17] Ben-Daya, M.; Raouf, A. A revised failure mode and effects analysis model. // International Journal of Quality \& Reliability Management. 13, 1(1996), pp. 43-47. https://doi.org/10.1108/02656719610108297

[18] Sankar, N. R.; Prabhu, B. S. Modified approach for prioritization of failures in a system failure mode and effects analysis. // International Journal of Quality \& Reliability Management. 18, 3(2001), pp. 324-336. https://doi.org/10.1108/02656710110383737

[19] Narayanagounder, S.; Gurusami, K. A. New Approach for Prioritization of Failure Modes in Design FMEA using ANOVA. // World Academy of Science, Engineering and Technology. 49, (2009), pp. 524-531.

[20] Breiing, A. J.; Kunz, A. M. Critical Consideration and Improvement of the FMEA. // Proceedings of the Int. Conference TMCE / Wuhan, China. 2002, pp. 519-530.

[21] Carlson, C. S. Achieving Safe, Reliable and Economical Products and Processes Using Failure Mode and Effects Analysis. A John Wiley \& Sons, Inc. Publication, 2012.

[22] FAM Secanj, Internal standarts, 2013.

[23] SRPS EN 60812:2011. Analysis techniques for system reliability - Procedure for failure mode and effects analysis (FMEA), Institute for Standardization of Serbia. Belgrade.

\section{Authors' addresses}

Eleonora Desnica, Ph.D. Associate professor University of Novi Sad, Technical Faculty "Mihajlo Pupin", Đure Đakovića bb, 23000 Zrenjanin, Republic of Serbia E-mail: desnica@tfzr.uns.ac.rs

Ivica Nikolić, Ph.D. Associate professor

EDUCONS University, Faculty of Business in Service, Vojvode Putnika 87, 21208 Sremska Kamenica, Republic of Serbia E-mail: naval_sl@uns.ac.rs

Vladimir Trninić, Mech. Eng.

FAM SEČANJ AI d.o.o.,

Partizanski put bb., 23240 Sečanj, Republic of Serbia

E-mail: Vladimir.Trninic@cimos.eu

Mirjana Bojanić, Mech. Eng. Assistant

University of Novi Sad, Faculty of Technical Sciences, Trg Dositeja Obradovica 6, 21000 Novi Sad, Republic of Serbia E-mail: bojanicm@uns.ac.rs 